\title{
EFEKTIFITAS WAKTU PEMBERIAN DAN KONSENTRASI \\ PACLOBUTRAZOL TERHADAP PERTUMBUHAN DAN HASIL KENTANG (Solanum tuberosum L.) VARIETAS SUPEJOHN
}

\section{EFFECTIVENESS OF TIME APLICATION AND CONCENTRATION OF PACLOBUTRAZOL ON GROWTH AND YIELD POTATO (Solanum tuberosum.L). VARIETIES SUPEJOHN}

\author{
Frangki Sambeka1), Semuel D. Runtunuwu2), dan Johannes E.X Rogi2) \\ 1)Balai Pengawasan dan Sertifikasi Benih Tanaman Pangan dan Hortikultura Provinsi Sulawesi Utara \\ 2)Fakultas Pertanian Universitas Sam Ratulangi Jl. Kampus Unsrat Kleak-Bahu Manado
}

\begin{abstract}
The study aimed to examine the influence of time of application and concentration of paclobutrazol on growth and yield of potato crop Supejohn held in District Modoinding South Minahasa regency, from March to June 2012, using a randomized block design with two factors. The first factor is the concentration of Paclobutrazol with four standards are: 0 ppm, 75 ppm, 100 ppm, $125 \mathrm{ppm}$ and the second factor is the provision of a three-level applications MST 4, 5 and 6 MST MST (Week After Planting). Based on research, the results of analysis of variance showed an interaction between application timing and concentration of paclobutrazol. Combination treatment with $125 \mathrm{ppm}$ paclobutrazol 6 WAP application time can give significant effect on plant height, number of chlorophyll content, percentage weight class tuber yield components in the form of increased crop production amounted to $45.04 \mathrm{~kg}$ / plot (24 plants) / range 52 . ton / ha by pressing the vegetative growth of plants.
\end{abstract}

Key words : Supejohn, time application, concentration, paclobutrazol

\section{ABSTRAK}

Penelitian bertujuan untuk mengkaji pengaruh waktu aplikasi dan konsentrasi paclobutrazol terhadap pertumbuhan dan hasil tanaman kentang Supejohn yang dilaksanakan di Kecamatan Modoinding Kabupaten Minahasa Selatan, dari bulan Maret sampai Juni 2012, dengan menggunakan Rancangan Acak Kelompok dengan dua faktor. Faktor pertama adalah Konsentrasi Paclobutrazol dengan empat taraf yaitu : 0 ppm, 75 ppm, 100 ppm, 125 ppm dan faktor yang kedua yaitu aplikasi pemberian dengan tiga taraf 4 MST, 5 MST dan 6 MST( Minggu Sesudah Tanam). Berdasarkan penelitian, bahwa hasil sidik ragam menunjukkan adanya interaksi antara aplikasi waktu pemberian dan konsentrasi paclobutrazol. Kombinasi perlakuan paclobutrazol 125 ppm dengan waktu aplikasi 6 MST dapat memberikan pengaruh nyata terhadap tinggi tanaman, jumlah kandungan klorofil, persentase kelas umbi komponen hasil bobot umbi yaitu berupa peningkatan produksi tanaman sebesar $45.04 \mathrm{Kg} / \mathrm{Plot}$ (24 Tanaman)/ berkisar 52. ton/ha dengan menekan pertumbuhan vegetatif tanaman.

Kata kunci : Supejohn, waktu pemberian, konsentrasi, paclobutrazol 


\section{PENDAHULUAN}

Provinsi Sulawesi Utara merupakan salah satu daerah sentra penghasil kentang dari 13 sentra penghasil kentang di Indonesia. Daerah sentra penghasil kentang di Provinsi Sulawesi Utara berada pada daerah dataran tinggi di kawasan Modassi (Modoinding, Modayag, Pasi) yang terletak di Kabupaten Minahasa Selatan, Bolaang Mongondow dan Bolaang Mongondow Timur.

Kentang, salah satu jenis tanaman hortikultura yang dikonsumsi umbinya, yang dikalangan masyarakat dikenal sebagai sayuran umbi. Tanaman kentang Supejohn banyak diusahakan oleh petani di Sulawesi Utara disamping kentang varietas Granola dan Atlantik. Tanaman ini merupakan kentang unggul spesifik dengan teknologi yang diterapkan oleh petani dengan keunggulannya adalah ukuran buahnya yang besar namun, rata-rata produksi kentang masih berkisar antara 13-17 ton/ha dibandingkan dengan kentang lainnya, seperti varietas Granola 26,5 toh/ha dan varietas Kikondo 24 ton/ha.

Kentang Supejohn produksinya rendah, diduga karena tanaman yang tergolong tinggi sehingga fotosintat yang dihasilkan oleh daun ke umbi menjadi jauh. Akibatnya, energi yang dibutuhkan semakin besar. Berdasarkan teori tersebut, maka untuk meningkatkan produktivitas tanaman kentang Supejohn, tanamannya harus dibuat lebih pendek dengan menggunakan zat penghambat tumbuh (ZPT) paclobutrazol.

Paclobutrazol merupakan zat penghambat pertumbuhan yang dapat menghambat pertumbuhan dan menyebabkan pengkerdilan serta meningkatkan kandungan klorofil daun sehingga aktifitas fotosintesis dapat berjalan dengan baik dan serta meningkatkan produksi dan menghambat sintesis giberellin (Salisbury and Ross, 2002).

Kentang termasuk tanaman semusim yang berbentuk semak atau perdu. Tanaman ini memiliki umur yang bervariasi antara 85-120 hari, dengan tinggi sekitar $50-120 \mathrm{~cm}$ dan diameter kanopi sekitar $50 \mathrm{~cm}$.

Tanaman kentang termasuk family Solanaceae dengan klasifikasi menurut Samadi
(1997) sebagai berikut : Kingdom: Plantae, Divisio : Spermatophyta, Sub Divisio : Angiospermae, Ordo : Solanales, Family : Solanaceae, Genus : Solanum, Spesies : Solanum tuberosum $\mathrm{L}$.

Tanaman kentang cocok ditanam di daerah dataran tinggi atau daerah pegunungan dengan ketinggian 1.000-3.000 m dpl. Ketinggian yang ideal yaitu pada kisaran 1.000-1.200 m dpl (Suryanto 2003).

Berdasarkan tekstur, tanah yang cocok ialah tanah andosol, lempung ringan yang terdapat sedikit pasir, sehingga memiliki drainase serta aerasi yang baik dan memiliki nilai pH antara 5-7, tergantung varietas yang digunakan (Samadi, 1997).

Tanaman kentang dapat tumbuh dan berproduksi dengan baik dengan suhu yang tepat, ${ }^{2} 0^{\circ} \mathrm{C}-24^{\circ} \mathrm{C}$ pada siang hari dan $8^{\circ} \mathrm{C}-12^{\circ} \mathrm{C}$ pada malam hari. Jika suhu rata-rata melebihi $23^{\circ} \mathrm{C}$, daun biasanya akan menjadi kecil dan jarak antara ruas menjadi panjang (Soelarso,1997).

Pertumbuhan tanaman kentang dibagi menjadi empat fase, yaitu pertumbuhan vegetatif, inisiasi, pembesaran, dan pemasakan umbi. Fase vegetatif dimulai sejak muncul tunas diperlukan waktu 2-5 minggu sampai inisiasi umbi, biasanya memerlukan waktu 2-4 minggu tergantung varietas dengan suhu di atas $20^{\circ} \mathrm{C}$, namun pertumbuhan umbi akan terhambat. Fase inisiasi dan pembesaran umbi, berlangsung selama 7-8 minggu, dimulai dengan pembentukan stolon dan dilanjutkan dengan pembesarannya dengan suhu ideal pembentukan umbi adalah $15-20^{\circ} \mathrm{C}$, bila terjadi suhu rendah di bawah $15^{\circ} \mathrm{C}$ maka laju pertumbuhan daun dan stolon akan terhambat. Fase pemasakan umbi memerlukan waktu 2-3 minggu (Sutater, 1986). Terlihat tiga perubahan penting pada tanaman, yakni kulit umbi mulai terbentuk, berat kering umbi mencapai maksimum serta bagian atas tanaman mulai berwarna kekuningan dan mati. Kisaran waktu pertumbuhan tanaman sejak tanam hingga panen sekitar 13-20 minggu (Lovatt,1997).

Paclobutrazol atau betha-[(chlorophenyl) methyl-alpha-(1,1-dimethyl)-H-1,2,4 triazole-1ethanoll)] (gambar 1), merupakan salah satu penghambat pertumbuhan yang berfungsi 
menghambat pertumbuhan bagian vegetatif tanaman menjadi mengecil dan merangsang pertumbuhan bunga. Dapat meningkatkan warna hijau (kandungan klorofil) daun dan mempengaruhi pembungaan, menghambat pembelahan sel dan pembesaran sel sub apikal tanpa menyebabkan pertumbuhan yang abnormal (Wattimena, 1988).

Penghambatan pertumbuhan yang diakibatkan, menghalangi tiga tahapan untuk produksi giberallin pada jalur terpenoid dengan cara menghambat enzim yang mengkatalisasi proses reaksi metabolis. Salah satu fungsi utama dari giberelin ialah untuk menstimulasi perpanjangan sel. Ketika produksi giberelin dihambat, pembelahan sel tetap terjadi namun sel-sel baru tidak mengalami pemanjangan sehingga terbentuknya cabang dengan panjang buku lebih pendek.

Paclobutrazol dapat diaplikasikan dengan beberapa cara, seperti penyemprotan bagian tajuk tanaman yang terletak di atas permukaan tanah (foliar application), penyiraman media (soil drench), dan injeksi pada batang (injection). Pengaruh retardan terhadap tanaman sangat bervariasi. Hal ini disebabkan (1) kemampuan yang berbeda dari daun, batang dan akar pada spesies yang berbeda untuk mengabsorpsi dan translokasi senyawa kimia; (2) adanya mekanisme penonaktifan dalam beberapa spesies; (3) perbedaan pola aksi retardan dalam tanaman (Menhennet, 1979).

Menurut Wattimena (1988) paclobutrazol bekerja dengan menghambat giberellin pada meristem sub apikal kemudian akan menyebabkan penurunan laju pembelahan sel sehingga menghambat pertumbuhan vegetatif yang diperlukan untuk membentuk bunga, buah dan perkembangan buah. Selain itu, Hutabarat (1994) menyatakan paclobutrazol juga dapat menekan pertumbuhan tajuk serta dapat meningkatkan pertumbuhan akar.

Intensitas cahaya dan lama penyinaran (panjang hari) penting untuk pertumbuhan tanaman melalui proses fotosintesis, semakin besar intensitas cahaya yang diterima tanaman maka akan mempercepat proses pembentukan umbi dan waktu pembungaan. Intensitas radiasi tersebut berpengaruh terhadap inisiasi umbi, stimulasi pertumbuhan awal umbi dan pertumbuhan batang. Sugito (1999) menjelaskan tiga faktor utama radiasi yang penting bagi tanaman yaitu kuantitas (intensitas), kualitas, dan periode lama penyinaran (fotoperiodisitas).

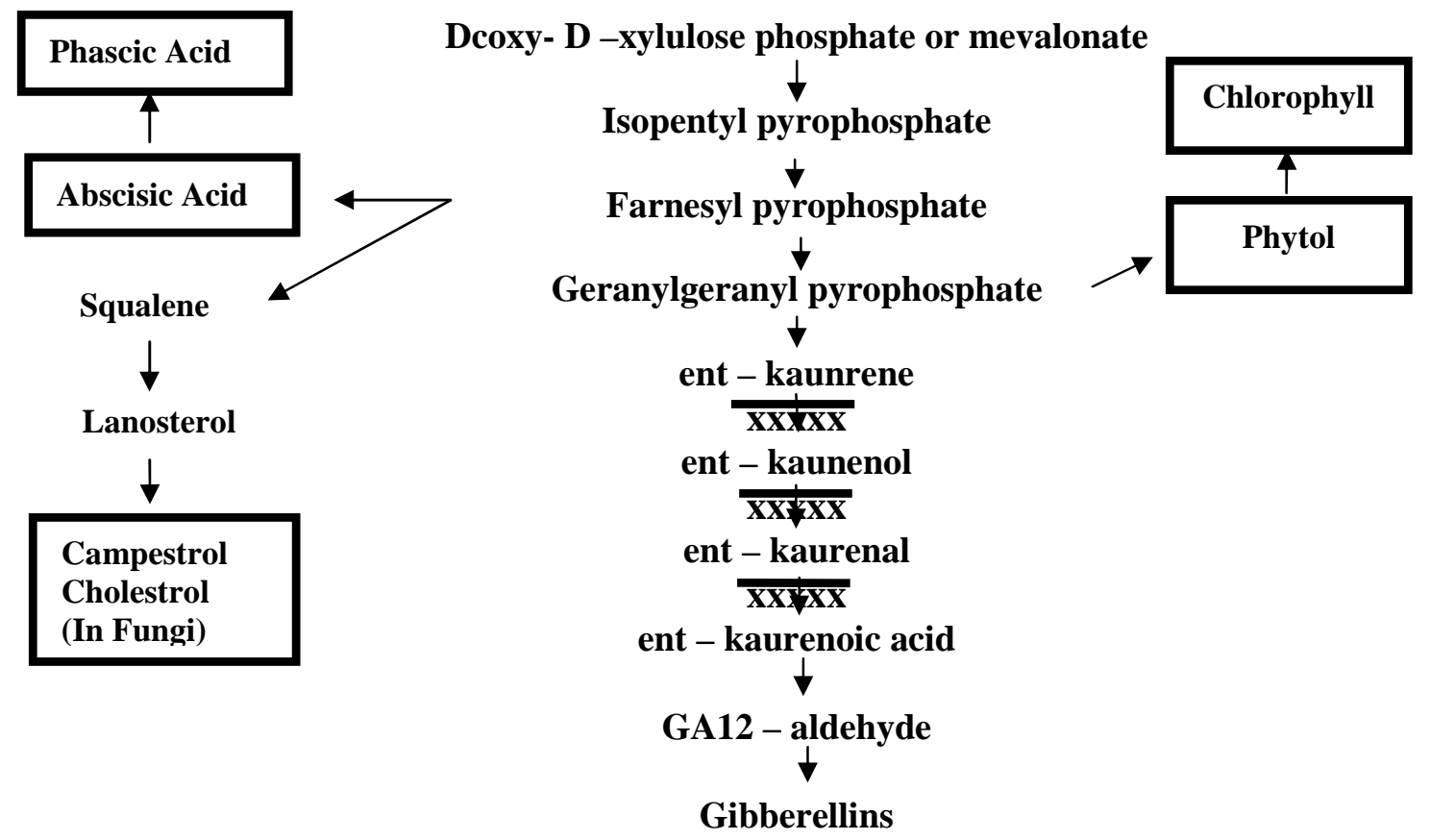

Gambar 1. Penghambatan Paclobutrazol Terhadap Giberallin (Chaney, 2004)

(Figure 1. Hindrance Paclobutrazol Concerning Giberallin 
Aspek intensitas yang banyak berperan dalam konversi energi matahari dibandingkan dengan dua aspek radiasi lain. Jones (1992) menambahkan radiasi matahari sampai pada permukaan daun tanaman dapat secara langsung dan berupa gelombang pendek dan panjang yang diterima melalui penerusan atmosfir, pemantulan awal dan pemantulan dari pemukaan tanah.

Reaksi cahaya dalam fotosintesis merupakan akibat langsung penyerapan foton oleh molekul-molekul pigmen seperti klorofil. Foton tidak seluruhnya memiliki tingkat energi yang cocok untuk mengeksitasi pigmen daun. Hanya foton dengan panjang gelombang antara 390-760 nm (photosynthetically active radiation/ PAR) yang memiliki energi yang cocok untuk fotosintesis (Gardner et.al., 1991).

Didalam proses fotosintesis, energi cahaya dikonversi menjadi energi kimia dalam bentuk ATP dan NADPH yang selanjutnya digunakan sebagai energi untuk mengubah karbondioksida menjadi gula dan pati dalam reaksi gelap serta pembagian fotosintat ke bagian tanaman yang bernilai ekonomis (Sinclair dan Muchow, 1999). Proses ini terjadi di dalam pigmen atau kompleks protein yang menempel pada membran tilakoid yang terletak pada kloroplas.

Dari masalah yang ada di lapangan bahwa belum diketahui kapan waktu aplikasi dan konsentrasi paclobutrazol terbaik yang tepat untuk mencapai produksi maksimal. Berdasarkan hal tersebut maka penelitian ini bertujuan mengkaji pengaruh waktu aplikasi dan konsentrasi paclobutrazol $(\mathrm{Pbz})$ terhadap pertumbuhan tinggi dan hasil tanaman kentang Supejohn di Kawasan Modasi yaitu Kecamatan Modoinding dengan manfaat agar dapat meningkatkan produktifitas tanaman kentang disentra produksi di Kawasan Modasi yaitu Kecamatan Modoinding di Provinsi Sulawesi Utara. Langka-langka yang dikaji adalah : waktu pemberian paclobutrazol mempengaruhi pertumbuhan tinggi dan hasil tanaman kentang Supejohn, konsentrasi paclobutrazol mempengaruhi pertumbuhan tinggi dan hasil tanaman kentang Supejohn, terdapat pengaruh interaksi antara waktu pemberian dan konsentrasi paclobutrazol terhadap pertumbuhan tinggi dan hasil tanaman kentang Supejohn.

\section{METODE PENELITIAN}

Penelitian ini dilaksanakan di Kecamatan Modoinding Kabupaten Minahasa Selatan selama empat bulan dari bulan Maret - Juni 2012 dengan ketinggian tempat $1100 \mathrm{dpl}$.

Bahan penelitian yang digunakan dalam penelitian ini adalah benih kentang varietas Supejohn, Goldstar 250 SC (Paclobutrazol), pupuk kandang, pupuk Urea, pupuk TSP, pupuk KCL, pestisida (Daconil 75 WP, Dithane, Victory Mix 8/64 WP dan Aseton, Aqua. Alat yang akan digunakan dalam penelitian ini adalah alat untuk membajak tanah, sprayer, timbangan, Spectrophotometer,Lux meter, gelas ukur,kertas saring, timbangan analitik, gunting, box pendingin, keranjang, karung, mortal, batang pengaduk, alumunium foil, tissu .

Penelitian ini dilakukan dalam bentuk percobaan lapangan, menggunakan Rancangan Acak Kelompok (RAK). Perlakuan yang dikaji terdiri dari 2 faktor, yaitu 1) Waktu pemberian Paclobutrazol 4 MST, 5 MST, dan 6 MST, 2) konsentrasi paclobutrazol (Pbz), yaitu $0 \mathrm{ppm}$ (control), 75 ppm, 100 ppm,dan 125 ppm. Setiap perlakuan diulang sebanyak 3 kali, sehingga terdapat sebanyak 36 kombinasi perlakuan (3x4x3).

\section{Prosedur Penelitian Pengolahan Tanah}

Pengolahan tanah dilakukan dengan tujuan menghancurkan dan menghaluskan tanah. Setelah pengolahan tanah selesai, kemudian diratakan, lalu dibuat plot sesuai dengan metode penelitian.

\section{Penanaman dan Pemberian Pupuk}

Sebelum dilakukan penanaman terlebih dahulu dibuat lubang tanam sedalam $5-10 \mathrm{~cm}$ dengan jarak tanam 40×60 cm. Masing-masing lubang dimasukan satu umbi bibit dengan posisi tunas menghadap keatas dan selanjutnya ditutup dengan tanah kira-kira setebal $5 \mathrm{~cm}$. Penyulaman dilakukan bila terdapat tanaman yang mati atau 
tumbuh tidak normal/sehat dan dilakukan hingga umur tanaman satu minggu setelah tumbuh. Pemberian pupuk diberikan sesuai dengan ukuran sesuai dengan kesuaian lahan dan jenis tanaman, dan pada tanaman kentang. Pupuk organik/pupuk kandang diberikan pada saat pengolahan tanah kedua, untuk pupuk NPK 15;15;15 diberikan pada saat tanaman berumur satu bulan setelah tanam bersama dengan pembubunan pertama. Pembubunan dilaksanakan sebanyak dua kali yaitu tanaman berumur satu bulan (4MST) dan pada saat tanaman berumur 14 MST.

\section{Aplikasi Paclobutrazol}

Paclobutrazol diaplikasikan sebanyak tiga kali pada umur 4 MST, 5 MST, 6 HST dengan konsentrasi yaitu 0 ppm; 75 ppm; 100 ppm; 125 ppm dengan cara disemprotkan pada seluruh bagian tajuk tanaman dari daun sampai bagian akar secara merata sampai tanaman basah.

\section{Pengendalian Hama dan Penyakit}

Pengendalian hama dan penyakit dilakukan secara intensif dengan pestisida. Pengendalian penyakit dilakukan dengan fungisida Dithane M-45, dosis 1-2g/l, Daconil dan Furadan. Frekwensi penyemprotan dilakukan 1 minggu sekali dan apabila terserang penyakit dilakukan 2 kali seminggu. Hama dicegah dengan insektisida Decis 2.5 EC dengan dosis $0.25-0.5 \mathrm{ml} /$. Interval penyemprotan dilakukan 1 minggu sekali.

\section{HASIL DAN PEMBAHASAN}

Secara umum hasil percobaan ini menunjukan kombinasi perlakuan waktu aplikasi dan konsentrasi paclobutrazol menekan pertumbuhan tinggi dan meningkatkan hasil (bobot umbi) tanaman kentang Supejohn. Penekanan/ penghambatan paclobutrazol terhadap pertumbuhan tinggi tanaman

Berdasarkan hasil pengamatan, ternyata waktu aplikasi dan konsentrasi paclobutrazol berpengaruh nyata terhadap tinggi tanaman mulai kelihatan pada pengamatan 6 MST dan konsisten sampai dengan pengamatan 12 MST dan ber- pengaruh juga pada bobot umbi tanaman dan bobot umbi/plot,jumlah klorofil dan produktivitas tanaman.

Pada Tabel 1 dan Gambar 2, konsentrasi paclobutrazol 125 ppm secara umum berpengaruh nyata terhadap komponen hasil bobot umbi yaitu berupa peningkatan produksi tanaman dengan menekan pertumbuhan vegetatif tanaman.

Dugaan bahwa pemberian paclobutrazol 125 ppm mampu menekan pertumbuhan vegetatif tanaman pada masa pengisian umbi yang terlihat dari pertumbuhan vegetatif batang. Adanya tekanan pertumbuhan vegetatif pada tinggi tanaman disebabkan oleh remobilisasi asimilat yang lebih besar untuk pembentukan umbi yang berdampak terhadap tingginya bobot umbi.

\section{Interaksi antara Waktu dan Konsentrasi Paklobutrazol dengan Kandungan Klorofil Daun, Fraksi Radiasi Terhadap Pertumbuhan dan Produksi Tanaman Kentang}

Pemberian paclobutrazol berpengaruh nyata terhadap tinggi tanaman kentang yang diaplikasikan pada umur 4 MST ,5, dan 6 MST dapat menghambat pertumbuhan dan pertambahan ruas batang dan meningkatkan kandungan klorofil daun sehingga aktifitas fotosintesis dapat berjalan dengan baik dan penghambatan terhadap tunas memacu hasil fotosintesis dipergunakan untuk pembentukan karbohidrat pada umbi (Tabel 1).

Hal ini sesuai dengan pernyataan Wieland dan Wampe (1985), bahwa pemberian paclobutrazol efektif diberikan melalui daun dan tanah. Zat tersebut ditranslokasikan melalui jaringan xilem dan mencapai tunas pucuk. Aplikasi paclobutrazol meningkatkan kandungan klorofil daun sehingga aktifitas fotosintesis dapat berjalan dengan baik dan penghambatan terhadap tunas memacu hasil fotosintesis dipergunakan untuk pembentukan karbohidrat pada umbi sehingga berpengaruh nyata terhadap bobot umbi/sampel dan bobot umbi/plot tanaman kentang. Sistem vasculer di sebelah titik tumbuh berfungsi sebagai penyimpan zat pengatur tumbuh dan menghambat biosintesa asam giberelat sehingga mengakibatkan pertumbuhan dan pemanjangan tunas berhenti. 
Tabel 1. Rataan Bobot Umbi Kentang Varietas Supejohn pada Saat Panen Berdasarkan Konsentrasi dan Waktu Aplikasi Paclobutrazol

(Table 1. Weight of the Potatoes Tuber Supejohn Variety When Harvest Time Based on the Concentration and Aplication, Time of Paclobutrazol)

\begin{tabular}{|c|c|c|c|c|}
\hline \multirow{3}{*}{ Waktu Aplikasi } & \multicolumn{4}{|c|}{ Konsentrasi Paclobutrazol (ppm) } \\
\hline & 0 & 75 & 100 & 125 \\
\hline & \multicolumn{4}{|c|}{ 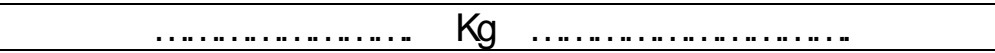 } \\
\hline $4 \mathrm{MST}$ & $0.77 b$ & $0.96 c$ & $1.30 f$ & $1.41 \mathrm{~g}$ \\
\hline $5 \mathrm{MST}$ & $0.78 b$ & $1.04 d$ & $1.48 h$ & $1.56 i$ \\
\hline 6 MST & $0.68 a$ & $1.10 \mathrm{e}$ & $1.60 j$ & $1.88 k$ \\
\hline
\end{tabular}

Bobot Umbi/ Tanaman (Kg)

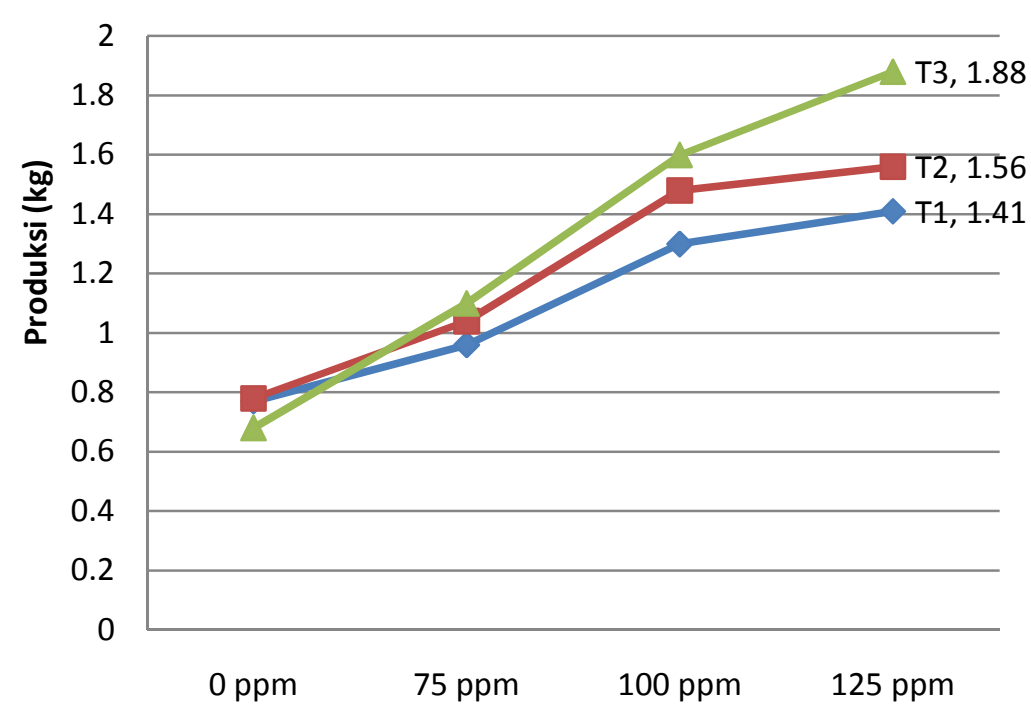

Gambar 2. Bobot Umbi/Tanaman $(\mathrm{Kg})$ pada Perlakuan Waktu Aplikasi dan Konsentrasi Paclobutrazol

(Figure 2. Tuber Weight on the Treatment Time of Aplication and Concentration of Paclobutrazol)

Tabel 2. Rataan Interaksi pada Berbagai Perlakuan Konsentrasi Paclobutrazol dengan Aplikasi waktu Pemberian pada 12 MST

(Table 2. Average Interaction on the Various Treatment Concentration Paclobutrazol with Aplication Time of Gift on 12 MST (week after plant)

\begin{tabular}{cccccc}
\hline Perlakuan & $\begin{array}{c}\text { Tinggi Tanaman } \\
\text { 12 MST }\end{array}$ & $\begin{array}{c}\text { Fraksi Radiasi } \\
\text { Pagi }\end{array}$ & $\begin{array}{c}\text { Fraksi Radiasi } \\
\text { Siang }\end{array}$ & $\begin{array}{c}\text { Kandungan } \\
\text { Klorofil Total }\end{array}$ & Bobot Umbi \\
\hline T3P0 & 76.55 & 0.36 & 0.26 & 1.407 & 0.68 \\
T3P1 & 57.30 & 0.34 & 0.30 & 2.77 & 1.10 \\
T3P2 & 57.63 & 0.38 & 0.31 & 2.977 & 1.60 \\
T3P3 & 57.13 & 0.40 & 0.33 & 2.853 & 1.88 \\
\hline
\end{tabular}

Berdasarkan hasil sidik ragam menunjukkan bahwa hasil interaksi antara perlakuan aplikasi waktu pemberian dan konsentrasi paclobutrazol berpengaruh nyata terhadap tinggi tanaman, bobot tanaman, bobot tanaman/plot, jumlah kandungan klorofil, persentase kelas umbi pada tanaman kentang. Hal ini diduga antara perlakuan aplikasi waktu pemberian dan konsentrasi paclobutrazol dapat mendukung dalam mempengaruhi per- tumbuhan dan produksi tamanan kentang secara bersamaan. Seperti kita lihat bahwa pemberian paclobutrazol yang diberikan dengan konsetrasi 125 ppm dengan waktu aplikasi 6 MST dapat menghambat pertumbuhan, namun menghasilkan bobot umbi yang significant karena proses fotosintesis yang lancar menghasilkan jumlah klorofil yang tinggi, sesuai dengan Yudiwanti (2007) tanaman yang berwarna hijau tua menunjukkan 
kandungan klorofil yang lebih tinggi dan memiliki keunggulan potensi hasil tinggi. Hal ini didukung oleh pernyataan Taiz dan Zeiger (2002) bahwa kandungan klorofil yang lebih tinggi secara visual ditunjukan oleh warna daun yang lebih hijau, maka daun yang lebih hijau tua akan lebih efisien dalam menangkap cahaya untuk fotosintesis dan aktifitas fotosintesis dapat berjalan dengan baik dan penghambatan terhadap batang dan tunas, memacu hasil fotosintesis yang pergunakan untuk pembentukan karbohidrat pada umbi.

Intensitas radiasi matahari erat kaitannya dengan ketinggian suatu tempat. Semakin tinggi tempat maka intensitas yang diterima akan semakin besar, begitu pula sebaliknya semakin rendah suatu dataran maka intensitas radiasi matahari yang diterima juga kecil. Cahaya memegang peranan penting dalam proses fisiologi tumbuhan terutama fotosintesis dan respirasi.

Bila intensitas cahaya yang diterima rendah maka jumlah cahaya yang diterima oleh setiap luas permukaan daun dalam jangka waktu tertentu rendah (Gardner, 1991). Kondisi kekurangan cahaya berakibat terganggunya metabolisme sehingga menyebabkan penurunan laju fotosintesis.

Pemberian konsentrasi paclobutrazol 125 ppm dan waktu aplikasi mempengaruhi jumlah intensitas cahaya matahari pada tanaman kentang Supejohn dan memberikan perbedaan yang nyata. Berdasarkan pengamatan hasil penelitian di lapangan jumlah produksi tanaman kentang Supejohn meningkat bobot umbi/plot dikarenakan intensitas cahaya tinggi. Menurut Anggrani 2005, Intensitas cahaya tinggi, dengan laju fotosintesis tinggi dapat menghasilkan jumlah buah pada tanaman kedelai dibandingkan pada intensitas rendah. Yoshida (1981), menjelaskan bahwa berkurangnya intensitas radiasi sampai 25\% pada fase pertumbuhan reproduksi dan pemasakan, bisa menurunkan produksi gabah padi IR 747B2-6 sampai 50\%. Salisburi dan Ross (1992) menjelaskan intensitas radiasi matahari yang rendah mengakibatkan kandungan klorofil daun berkurang dan selanjutnya menurunkan laju fotosintesis. Merurut Larcher (1980) menyebutkan, sebagai tanaman C3 tanaman masih mampu melakukan fotosintesis optimal pada tingkat cahaya $30-50 \%$, namun bila intensitas yang diterima semakin rendah maka akan mengganggu proses fotosintesis dan akan menurunkan laju translokasi fotosintat pada sink oragan dalam hal ini umbi kentang Supejohn.

Adanya pengurangan intensitas ini akan mengakibatkan kandungan klorofil dan kerapatan stomata berkurang dan selanjutnya menghambat laju fotosintesis. Hal serupa dilaporkan oleh Mills (2001) bahwa pembentukan umbi sangat dipengaruhi intensitas radiasi matahari, suhu dan kelembaban. Bila intensitas radiasi rendah maka kandungan klorofil daun berkurang yang mengakibatkan translokasi asimilat ke bagian umbi terganggu dan akhirnya umbi yang terbentuk cenderung kecil.

\section{KESIMPULAN DAN SARAN}

\section{Kesimpulan}

Kombinasi perlakuan paclobutrazol 125 ppm yang disemprot pada 6 MST mampu menekan pertumbuhan tinggi tanaman, meningkatkan kandungan klorofil total dan meningkatkan penyerapan radiasi matahari oleh tajuk tanaman (fraksi radiasi menjadi lebih kecil) serta meningkatkan bobot umbi pertanaman (dari $0,78 \mathrm{~kg}$ menjadi 1,88 kg), dan meningkatkan bobot umbi per petak (dari $16.40 \mathrm{~kg}$ menjadi 45,04 kg).

Hasil interaksi waktu aplikasi dan konsentrasi paclobutrazol $125 \mathrm{ppm}$ pada saat tanaman kentang supejohn berumur 6 MST meningkatkan hasil $1.88 \mathrm{~kg}$ pertanaman atau 52 ton/ha.

Aplikasi paclobutrazol pada tanaman kentang Supejohn harus dilakukan pada minggu keenam sesudah tanam (6 MST) dengan konsentrasi $125 \mathrm{ppm}$.

\section{Saran}

Teknologi retardan dapat digunakan dalam upaya meningkatkan produksi tanaman kentang Supejohn di sentra produksi, yaitu kawasan Modasi (Modoinding, Modayak dan Passi). Waktu yang tepat untuk aplikasi adalah 6 Minggu sesudah Tanam (6 MST) dengan konsentrasi 125 ppm. 


\section{DAFTAR PUSTAKA}

Anggarani, S.D. 2005. Analisis Aspek Agronomi dan Fisiologi Kedelai (Glycine max (L) Merr.) pada Kondisi Cekaman Intensitas Cahaya Rendah. Skripsi. Departemen Budidaya Pertanian, Fakultas Pertanian, Institut Pertanian. Bogor. 59hal

Chaney, E. R. 2004. Paclobutrazol: More Than Just a Growth Retardant. Pro-Hort Conference, Peoria, Illinois, February 4th. Department of Forestry and Natural Resources. Purdue University.

Gardner, F.P., R. Brent, P. Roger, L. Mitchell. 1991. Physiology of Crop Plants. Terjemahan $\mathrm{H}$ Susilo. UI Press. Jakarta.

Hutabarat, R. 1994. Pengaruh media, BAP dan Paclobutrazol Terhadap Produksi Umbi Mini Kentang (Solanum tuberosum L.) Kultivar Red Pontiac. Tesis. Fakultas Pascasarjana IPB. Bogor. 94 hal.

Jones, H.G. 1992. Plants and Microclimate. A Quantitative Approach to Environmental Plant Physiology. 2nded. New York: Cambridge Univ. Press.

Larcher, W. 1980. Physiological Plant Ecology. New York: Trans. M.A. Biederman-Thorson.

Lovatt, J. 1997. Potato Information Kit. The Agrilink Series. Queensland: The State of Queensland, Department of Primary Industries.

Frederick and M. Jessica. 2003. Physiologycal Effects of Paclobutrazol During Plant Stress. Domonican University of California. http://www.abstracs.aspb.org/Pb2008/P30/ 0697.htm. California.

Mills HA. 2001. Potato (Solanum tuberosum L.) UGA Horticulture. Univ. Of Georgia. www. uga.edu/vegetable/potato.

Menhennet, R. 1979. Use of Glass House Crops. p. 27-38. In D. R. Clifford and J. R. Lenton.. Recent Development in The Use of Plant Growth Retardants. Brit. Plant Growth Regulator Group. London.

Salisbury, F.B., and C.W. Ross. 1992. Fisiologi Tumbuhan Jilid 2. Terjemahan dari: FB Salisbury and CW Ross. Plant Physiology 4th Edition. Penerbit ITB Bandung. 173 hal.

Physiology. Wadsworth Publishing Company, Belmont, California. Hal 319329.

Samadi, B. 1997. Usaha tani Kentang. Kanisius, Yokyakarta.

Sinclair, J. and Muchow. 1999. Light adaptation/acclimation of photosynthesis and the regulation of Ribulose-1,5Biphosphate Carboxylase activiy in sun and shade plants. Plant Physiology 91:379-386.

Sugito, Y. 1999. Ekologi Tanaman. Unibraw Press. Malang.

Suryanto, A. 2003. Peningkatan Efisiensi Energi Tanaman pada Pertanaman Kentang (Solanum tuberosum L.) di Dataran Tinggi melalui Perbaikan Teknik Budidaya. Disertasi. Malang: Universitas Brawijaya, Program Pascasarjana.

Sutater, T. 1986. Modifikasi Linkungan Mikro Pada Tanaman Kentang. Fakultas Pasca Sarjana. Institute Pertanian Bogor.

Soelarso, B.R. 1997. Budidaya Kentang Bebas Penyakit, Kanisius Yokyakarta.

Taiz, L. and E. Zeiger. 2002. Plant Physiology Third Edition. Sinauer Associates Inc. Publishers. Massachussetts. 690p.

Wattimena, G. A. 1988. Zat Pengatur Tumbuh Tanaman. Lab. Jaringan Tanaman. PAU Bioteknologi IPB. Bogor. 145hal.

Wieland, C.L dan Wampe. 1985. Control of Vegetatif Growth of Stone Fruits with Paclobutrazol. http://www.ag.auburn.edu/landscape/terap an idx.php.artikel. $112 \mathrm{p}$.

Yudiwanti. 2007. Galur Kacang Tanah Berdaun Hijau Tua; Keunggulan dan Pengendalian Genetiknya. Makalah Oral. Prosiding Seminar Nasional Hasil Penelitian yang dibiayai oleh Hiba Kompetetif; Bogor,1-2 Agustus 2007. HIm 143-146.

Yoshida, S. 1981. Fundamental of Rice Science. Phippines: IRRI Los Banos. 
